\title{
Field of the Colored Dissolved Organic Matter Concentration in the Sea of Azov and the Kerch Strait Waters Based on Optical Observations
}

\author{
P.D. Lomakin, A.I. Chepyzhenko, A.A. Chepyzhenko \\ Marine Hydrophysical Institute, Russian Academy of Sciences, Sevastopol, Russian Federation \\ e-mail:annachep87@yandex.ru
}

\begin{abstract}
The notions on the sources and structure of the colored dissolved organic matter concentration field in the Sea of Azov and the Kerch Strait waters are first obtained on the basis of the results of several expeditions carried out by the scientists of Marine Hydrophysical Institute. It is shown that in the Sea of Azov the main natural source of this substance is related to the river runoff, particularly significant for the northern and eastern coasts; in the Kerch Strait - with the Black Sea subsurface waters. It was found that transformed river waters with high dissolved organic matter content do not penetrate into the southern sea area and the Kerch Strait, whereby in the predominant part of the Azov Sea waters the colored dissolved organic matter typical concentration defined by the optical methods turns out to be by an order lower than the available calculated estimates. Our measurement data for the Black Sea waters were in line with the earlier defined dissolved organic matter content by chemical methods. In the colored dissolved organic matter field of the Kerch Strait the frontal zone coinciding with the main thermohaline front, that delimits the interacting Black Sea and Azov Sea waters, is revealed. The lens with high colored dissolved organic matter concentration related to anthropogenic influence of harbors and industrial plants situated at the shore, the sewage collectors, cargo terminals, off-shore transshipment sites and ground landfills are revealed.
\end{abstract}

Keywords: colored dissolved organic matter, the Sea of Azov, the Kerch Strait.

DOI: 10.22449/1573-160X-2016-5-71-83

(C) 2016, P.D. Lomakin, A.I. Chepyzhenko, A.A. Chepyzhenko

(C) 2016, Physical Oceanography

Introduction. Colored dissolved organic matter (CDOM) is an important parameter of water environment presenting in all types of natural waters. It almost has not been investigated in terms of classic oceanography up to the present time. The reason for this is the absence of reliable measuring instruments which would provide operative acquisition of mass data on concentration of this matter in the water areas of our interest. This explains insufficient amount of corresponding data in modern oceanographic databases, the absence of investigations on CDOM fields and current ambiguity of the opinions of various researchers on typical natural concentration of this element for the oceans, seas, their particular regions and other bodies of water.

Thus, according to [1], CDOM content in natural bodies of water varies within 20 - $50 \mathrm{mg} / \mathrm{l}$ range. In accordance with [2], in the upper layer of the Black Sea central part typical concentration of this element is by an order lower: $\sim 2 \mathrm{mg} / \mathrm{l}$. In [3] CDOM content in the waters of the Atlantic and the Pacific Oceans equals, on average, $2 \mathrm{mg} / \mathrm{l}$. In the Baltic and the Caspian Sea it varies within $5-6 \mathrm{mg} / \mathrm{l} \mathrm{range,}$ and in the Sea of Azov it is characterized by the maximum concentration - up to 10 $\mathrm{mg} / \mathrm{l}$.

In the present paper it was an attempt to investigate CDOM concentration field in the Sea of Azov and in the Kerch Strait on the basis of classic oceanography methods. CDOM characteristic concentration was refined, typical large-scale signs 
of field structure of this matter were revealed. Issues concerning the CDOM main sources were considered, water areas and their effects were assessed.

Initial data and research techniques. Regular empirical investigation of DOM fields at the selected shore areas of the Black Sea and the Sea of Azov became possible due to the use of optical methods for determining the concentration of this substance. In 2001, the performance of such measurements and collection of relevant information were initiated in the collected water samples under laboratory conditions in Marine Hydrophysical Institute (MHI) for the first time. DOM concentration assessment was carried out using fluorescent method ( $f D O M)$ with calibration within quinine sulfate equivalents (QSE) standards and conversion into weight units $\left(r^{2}=0.97\right)$ according to Yellow Springs Instrument Company (YSI Inc.) recommendations and comparison results [4].

Similar measurements have been performing by means of "Condor" probe [5] since 2005. This instrument was applied in series of MHI complex expeditions in the Black Sea and the Sea of Azov coastal waters in 2001 - 2015. As a result, an oceanographic database, that provided insights into CDOM sources and content fields in the considered water areas, was compiled.

For the analysis represented in the present paper the following information on Marine Hydrophysical Institute expeditionary investigations (Table) were used. Initial selection contained 1013 stations, 159 of them - in the Sea of Azov and 854 - in the Kerch Strait.

\section{The data of MHI expeditionary research carried out in the Sea of Azov and the Kerch Strait with CDOM content fixation}

\begin{tabular}{lc|c|c}
\hline \multicolumn{1}{c}{ Region } & Date & Amount & DOM, mg/l \\
\hline The Don estuary & June 2015 & 8 (sea), & $15-30(\mathrm{~s})$, \\
& & 44 (river) & $40-62(\mathrm{r})$. \\
Berdyansk Gulf & December 2007 & 16 & $1-22$ \\
$\begin{array}{l}\text { The center of the sea } \\
\text { Western part of the sea }\end{array}$ & September 2002 & 12 & $1-3$ \\
$\begin{array}{l}\text { The Sivash Lake } \\
\text { Southern part of the }\end{array}$ & June 2013 & 13 & $2-3$ \\
sea & June 2013 - October 2015 & 23 & $1-2$ \\
The Kerch Strait & August 2003 - August 2014 & 87 & $1-2$ \\
\hline
\end{tabular}

Water area of the Sea of Azov is unevenly and poorly provided with initial data. There are no data in its Eastern part. In the open central area of the sea only 12 probings (Kerch - Berdyansk section) with CDOM content determination were carried out. Most volume of data under analysis fell on coastal area. The surveys are located along the perimeter of the sea, from the Don estuary to the Northern narrowness of the Kerch Strait (Table). The range of depths studied in the Sea of Azov is $0.5-12.2 \mathrm{~m}$.

It should be pointed out that in spite of small amount of data on CDOM, its analysis allowed us to specify the CDOM concentration value characteristic of the Sea of Azov and considered to be high in comparison with the waters of other seas 
(according to [3] it made up $10 \mathrm{mg} / \mathrm{l}$ ) and oceans, as well as to gain an insight about the sources and field structure of this matter.

Unlike the Sea of Azov, the Kerch Strait water area, well-provided with initial data, included the strait itself and adjacent pre-strait areas of the Sea of Azov and the Black Sea (Table). The range of depths studied in the Kerch Strait area is 0.5 $50.7 \mathrm{~m}$.

All over the considered water area the probing was carried out with $0.1 \mathrm{~m}$ depth step. Interpretation of CDOM content field structure was performed using the data on dynamics and thermohaline structure of waters.

Discussion of the results. The Sea of Azov. Let us consider features of CDOM content field structure at the areas of the Sea of Azov coast from the Don estuary to the Kerch Strait. According to results of oceanographic survey carried out by MHI in the Don estuarine area (Fig. 1), the following facts were revealed. River waters are characterized by high CDOM concentration. The field of this matter is weakly stratified. $\operatorname{CDOM}(z)$ distribution here is an insignificantly changing depth function. At the river areas which are distant from the estuary CDOM content reached $50-62 \mathrm{mg} / \mathrm{l}$. Towards the estuary it was $3-4$ times lower (Fig. 1, a). Along the seaward part of the Don estuarine area in a narrow coastal strip with up to 1 mile width (where the salinity increased from 0 to $0.8 \mathrm{psu}$ ) CDOM concentration sharply decreased down to $14-20 \mathrm{mg} / \mathrm{l}$ minimum values. Here, in CDOM content field strongly pronounced front section was observed (Fig. $1, b)$.

Unfortunately, water area of the testing survey did not allow us to trace the seaward boundary of this frontal formation. However, as follows from the CDOM horizontal gradient value, it did not spread far into the open waters. Therefore, CDOM main mass (related to the Don runoff) was likely to be concentrated in the coastal strip of Taganrog Bay Northern part. This assumption is confirmed by the results of expeditionary studies discussed below.

According to materials of the survey carried out by MHI in December 2007, we found CDOM-saturated alongshore stream of Western direction with 10 $20 \mathrm{~cm} / \mathrm{s}$ velocity near the Northern shores of the Sea of Azov (in Berdyansk Gulf). In the system of Western general transport the transformed river waters with $7.5-$ 7.7 psu salinity (Fig. 2, b) and high (against the overall background) CDOM content (up to $17-22 \mathrm{mg} / \mathrm{l}$ ) (Fig. 2, c) were found.

In four samples taken from the sea surface (during the probing) seawards from the main site, at $\sim 1.5-2.2$ miles distance from the shore, CDOM concentrations appeared to be low $(1.2-2.3 \mathrm{mg} / \mathrm{l})$, with typical for the open waters $10.0-$ 10.1 psu salinity [6].

Let us remind that Berda River inflows small (by its water area) Berdyansk Bay and transformed waters of the Don and the Kalmius rivers are spread westwards along the Northern coast of the Sea of Azov in the global system (on the scale that the Sea of Azov has) of cyclonic circulation. That means that the main source and factor of DOM field formation both near the Northern shore of the sea and in Taganrog Bay is related to the river runoff.

It should be pointed out that high concentration of CDOM at the considered near-estuary areas was observed in a narrow coastal strip with a width not more than 1 mile. 

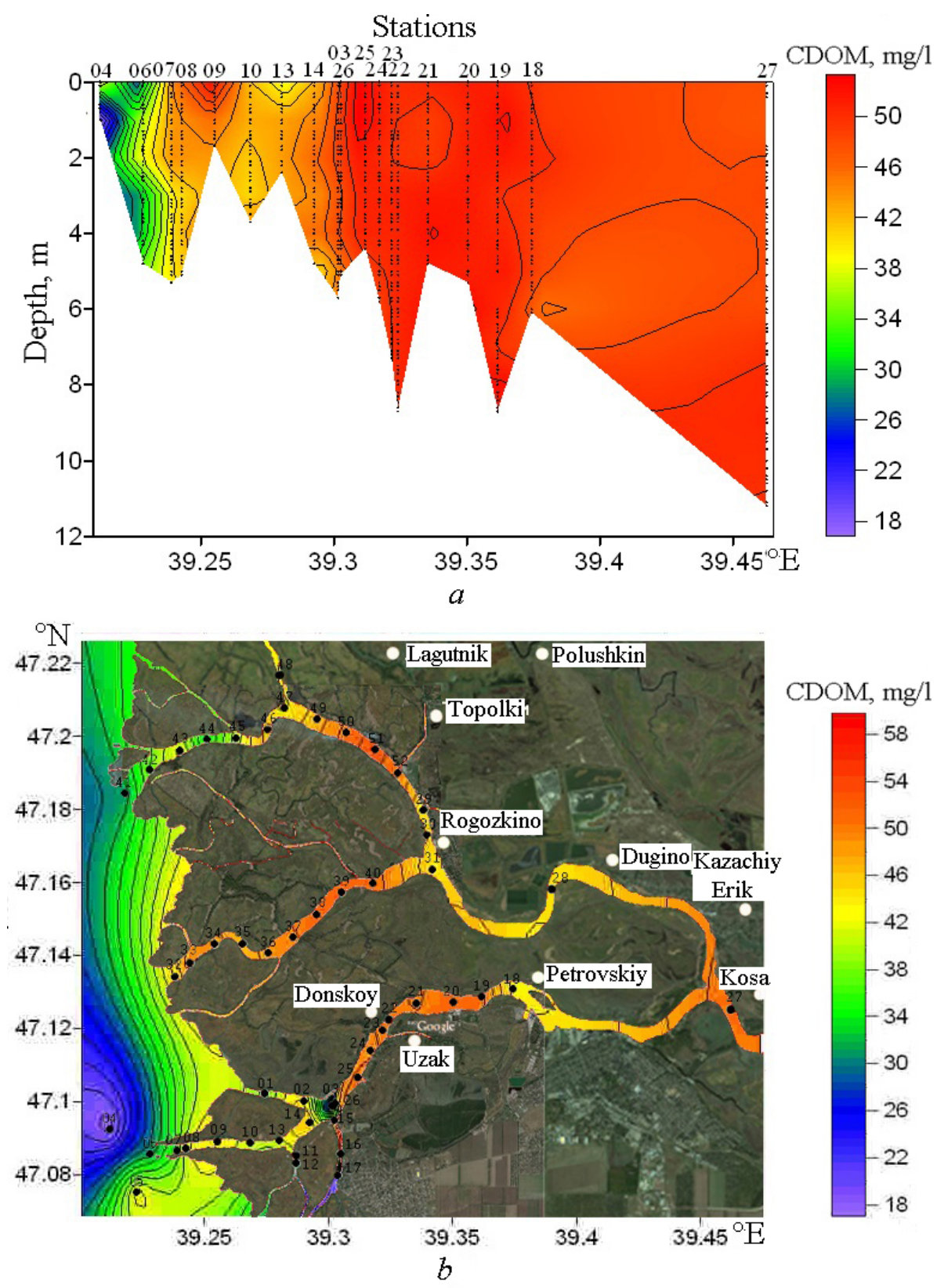

Fig. 1. CDOM vertical distribution on the section that goes along the southern stream of the Don River (a) and at the bottom distribution in the Don estuary (b) on June 15, 2015

Sharp CDOM concentration decrease in the river estuaries can be explained by mutual coagulation process which can be observed when the mixing of sea and river waters takes place. Seawater salt ions are adsorbed on charged colloidal particles of river water and this leads to their coagulation. A significant amount of slit is gradually accumulated at the bottom [7] for this reason. 


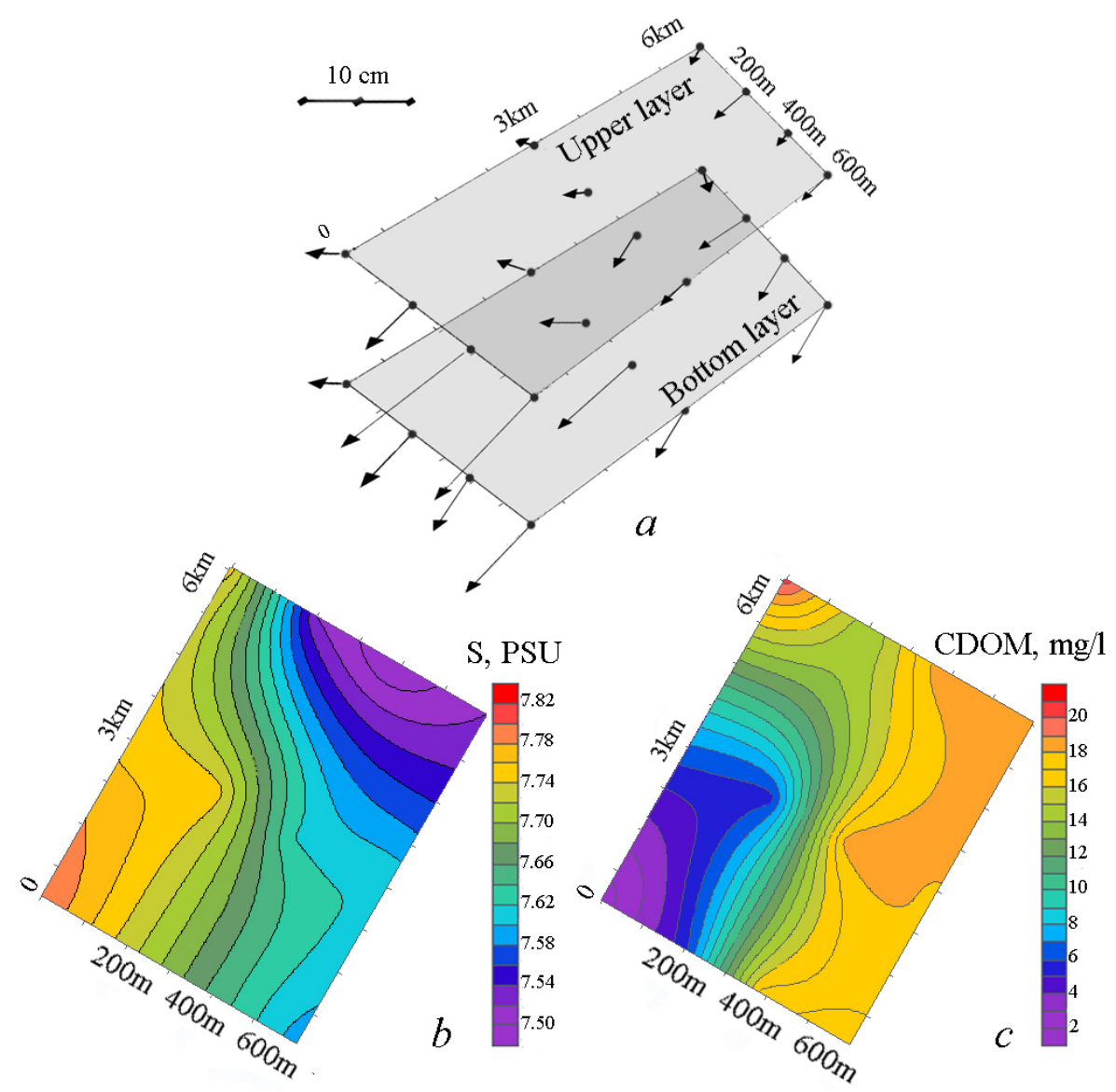

Fig. 2. Scheme of currents $(a)$, salinity distribution $(b)$ and CDOM content $(c)$ at the surface of the Sea of Azov on December 7, 2007 near Berdyansk Gulf

Apparently, similar properties are also characteristic of CDOM field in the Eastern part of the sea (no data for this area) where it is formed under effect of the rivers inflowing there. The Kuban River is the most full-flowing one among them.

The waters of open Sea of Azov areas as well as its Western and Southern coastal regions that are not affected by river runoff appeared to be significantly less saturated with CDOM. For these regions (which are the main part of the Sea of Azov water area) CDOM characteristic concentration $(\sim 2 \mathrm{mg} / \mathrm{l})$ is approximately the same as for the waters of the Black Sea, the Atlantic and the Pacific Ocean [3].

In the middle of the sea on the Kerch - Berdyansk section CDOM concentration varied within 1.4 - $3.2 \mathrm{mg} / \mathrm{l}$ range. In June 2013, along the Eastern coast of Arabat Spit in $1-2 \mathrm{~m}$ layer it made up $2.2-2.8 \mathrm{mg} / \mathrm{l}$ at 11.5 psu mean salinity. Along the perimeter of Sivash Lake, at the areas with $0.2-0.7 \mathrm{~m}$ depths CDOM concentration was also small: $1.2-2.5 \mathrm{mg} / \mathrm{l}$ (Table). In the places of spring 
water discharges local maximums of CDOM content (up to $3.0-3.7 \mathrm{mg} / \mathrm{l}$ ) were registered.

The research of CDOM field in the southern part of the Sea of Azov and in the Kerch Strait carried out at sufficiently provided selection (Table) revealed the following facts. Transformed river waters do not penetrate this area, as well as western regions of the sea. According to climatic data [8], this area is characterized by the maximum salinity (against the one of the region), up to $12.0-12.5 \mathrm{psu}$. During the entire observation period, the waters with high salinity $(10.0-11.7 \mathrm{psu})$ and low CDOM content (usually, not more than $2 \mathrm{mg} / \mathrm{l}$ ) were registered here.

CDOM content field in the Sea of Azov is characterized by two main regions. These regions are: eastern and northern areas (affected by river runoff) with typical high concentration of this matters ( 10 - $30 \mathrm{mg} / \mathrm{l})$ and another vast region which includes open and coastal waters of western and southern sea coasts where CDOM concentration is by an order lower $(\sim 1-3 \mathrm{mg} / \mathrm{l})$.

CDOM vertical stratification in the investigated areas of the Sea of Azov is weak. In its clear waters CDOM content field is vertically homogeneous. It insignificantly increases with depth by $0.1-0.3 \mathrm{mg} / \mathrm{l}$ from the surface to the nearbottom horizon.

In general, for the unpolluted waters of the Sea of Azov a close correlative feedback (with $R_{S / \mathrm{CDOM}}=-0.80$; $\mathrm{CDOM}$ linear regression equation $=30.87-2.78 \times$ $S$ ) between the salinity and CDOM content was found out (Fig. 3). At qualitative level this confirms the significance of river runoff as a factor that forms the field of element under investigation in coastal regions in the East and North of the sea and minimum saturation of waters with dissolved organics with the maximum salinity in its southern part.

It should be pointed out that similar patterns for the USA ocean coast were revealed in [9], where the significance of river runoff as the main CDOM source and the presence of correlative feedback with high coefficient between the salinity and concentration of this matter were demonstrated. 


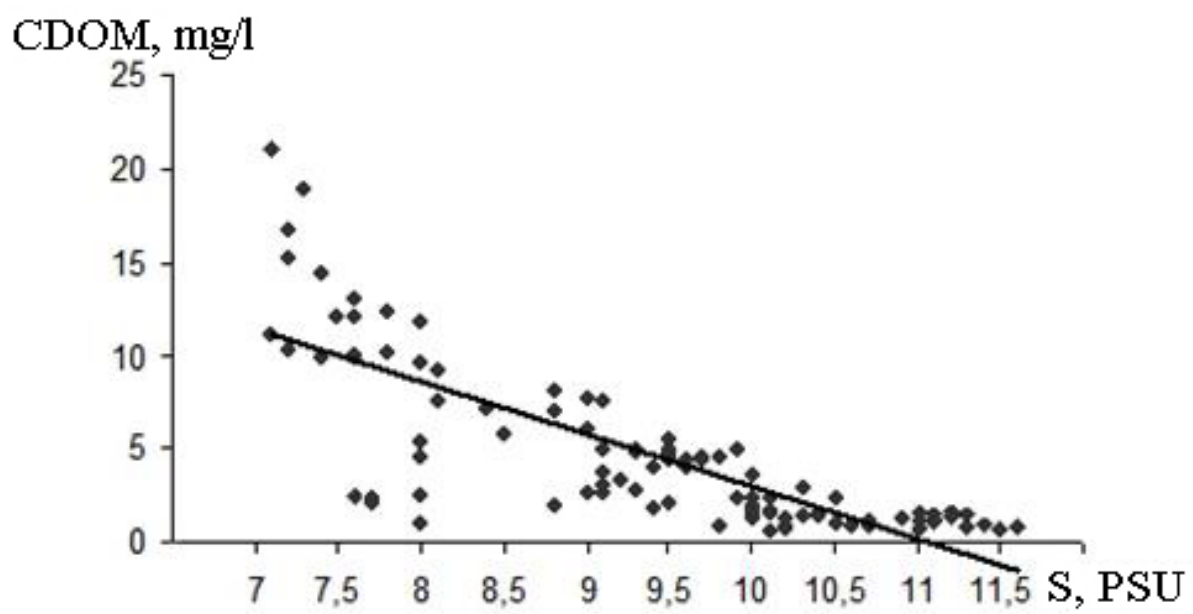

Fig. 3. A line of regressive relation between the salinity and CDOM content in unpolluted waters of the Sea of Azov

Relation between CDOM concentration and salinity in polluted waters of the Sea of Azov and the Kerch Strait is absent.

The Kerch Strait. When analyzing the structure of CDOM content field in the Kerch Strait on the basis of oceanographic surveys the following feature was revealed. In the field of this value there is a sufficiently marked front which coincides with main thermohaline front section that delimitates the waters of the Sea of Azov and the Black Sea interacting in the strait. Thus, the waters of the Sea of Azov and the Black Sea which penetrate into the strait have their own CDOM concentration in addition to the known thermohaline features. Moreover, this concentration in the Sea of Azov waters is lower than in the Black Sea ones.

As an example, in Fig. 4 the distribution of temperature, salinity and CDOM content on the Kerch Strait surface according to data of expedition carried out on July 10, 2010 by MHI is represented. It is obvious that in the fields of all three environment elements front section (directed mainly from South-West to NorthEast) main part of which is located in southern area of the strait is well marked. The front divided warmed $\left(25.7-26.1^{\circ} \mathrm{C}\right)$, less saline $(11.5-13.0 \mathrm{psu})$ and less saturated with CDOM $(0.82-1.10 \mathrm{mg} / \mathrm{l})$ waters of the Sea of Azov from relatively cool $\left(24.7-26.1^{\circ} \mathrm{C}\right)$, more saline $(16.0$ - $18.0 \mathrm{psu})$ and saturated with CDOM (1.50 - $1.67 \mathrm{mg} / \mathrm{l})$ Black Sea waters.

Elementary statistical assessments represented in Fig. 5 demonstrate that the situation described above is not accidental, and that the front section in the CDOM field is a typical large-scale water structure element in the Kerch Strait unpolluted waters. To prove this fact, it was necessary to determine CDOM characteristic concentration in unpolluted waters of the Sea of Azov and the Black Sea situated to the North and to the South from the main thermohaline front, respectively. 

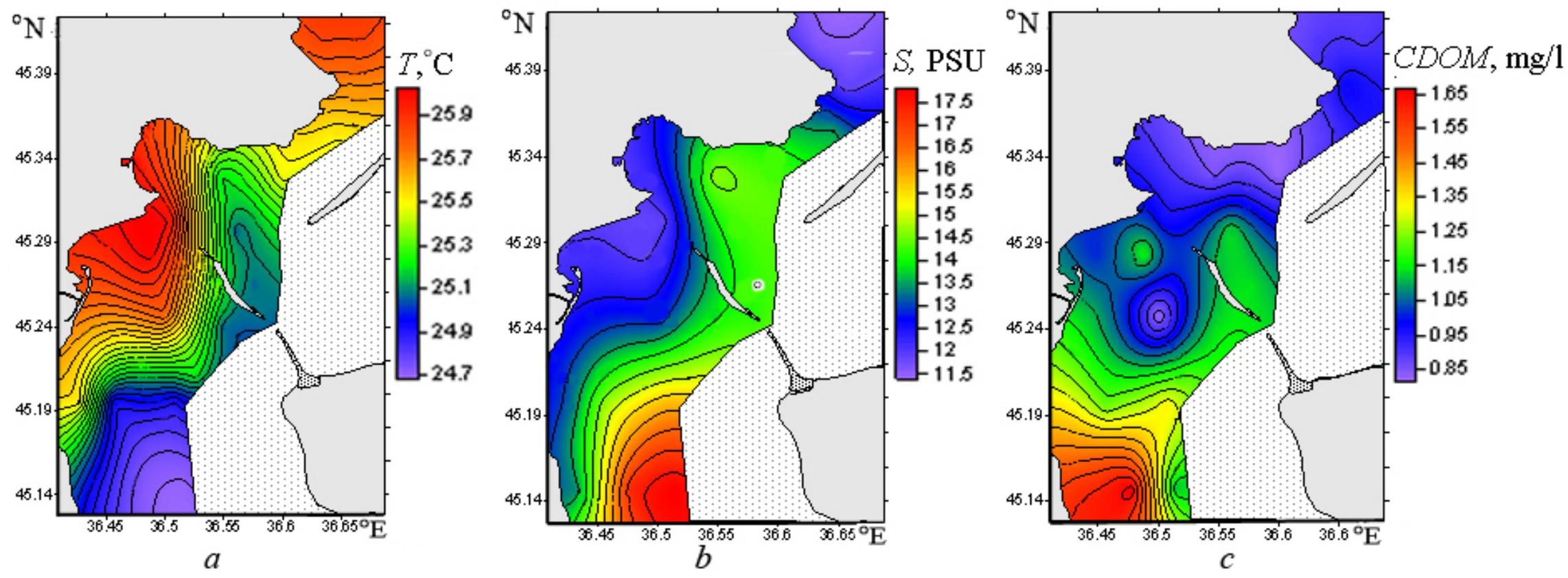

Fig. 4. Distribution of temperature (a), salinity (b) and CDOM concentration (c) on the surface of the Kerch Strait on July 10, 2010 

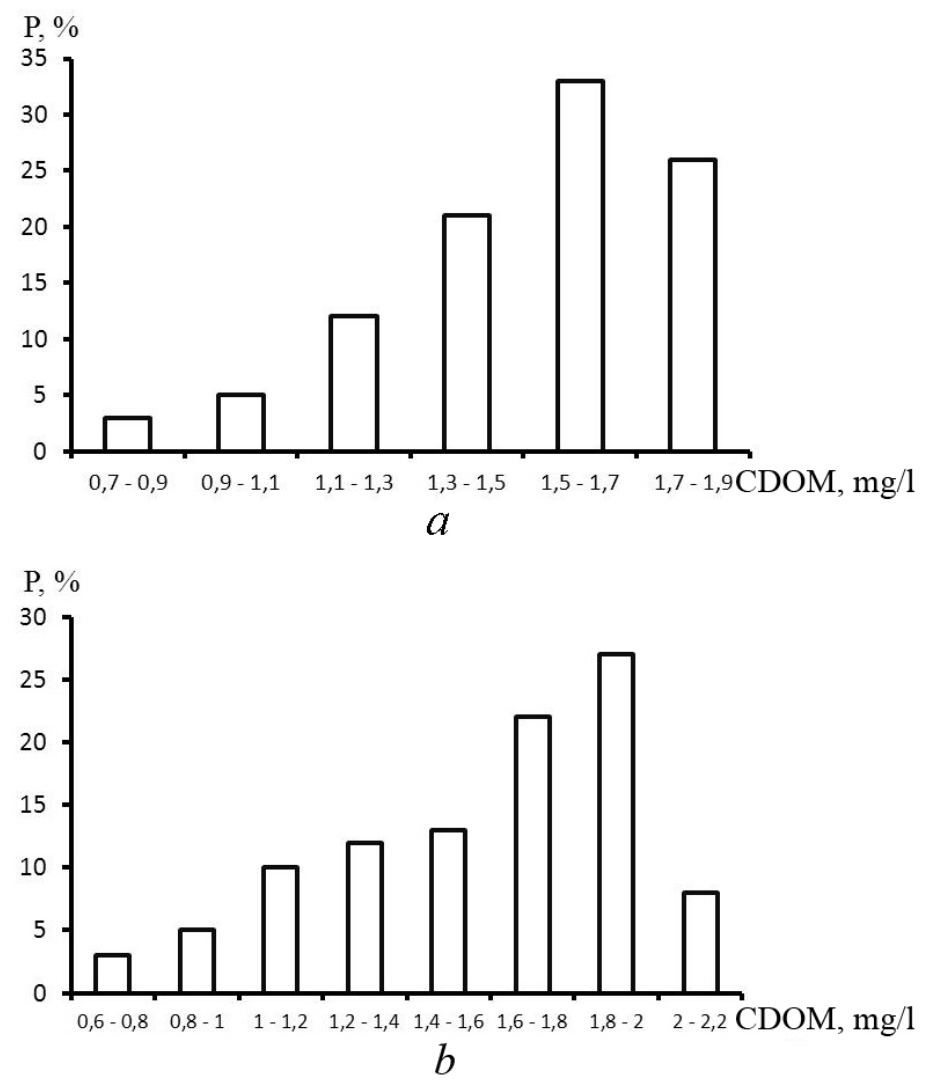

Fig. 5. Histograms $(P)$ of CDOM concentration recurrence for unpolluted waters of the Sea of Azov $(a)$ and the Black Sea $(b)$ interacting in the Kerch Strait

On the basis of available information it is revealed that in thermohaline field the main front section of the Kerch Strait is tilted towards the Black Sea and its width is about 3 miles. Both on the surface and at the bottom it is located between 12 and 16 psu isohalines.

According to $S<12$ psu (the Sea of Azov waters), $S>16$ psu (the Black Sea waters) criteria, two probing samples with determination of CDOM content on the surface were formed. Then, from each CDOM concentration sample there were filtered high (related to anthropogenic effect) values by conditional criteria on $\mathrm{CDOM}<2.2 \mathrm{mg} / \mathrm{l}$ (characteristic concentration of dissolved organic matter for clear waters of the Black Sea [2]). Histograms of CDOM concentration recurrence in unpolluted waters of the Sea of Azov and the Black Sea interacting in the Kerch Strait (Fig. 5) were calculated using two residual samples.

As a result, it turned out that on the surface in clear waters of the Sea of Azov CDOM content varied from 0.7 to $1.8 \mathrm{mg} / \mathrm{l}$; most frequently, (with $33 \%$ repeatability) the values within $1.5-1.7 \mathrm{mg} / \mathrm{l}$ range were observed there (Fig. 5, a). Therefore, the criterion of CDOM content $\lesssim 1.6 \mathrm{mg} / \mathrm{l}$ can be taken as an indicator of natural norm of CDOM content in the Sea of Azov waters penetrating the strait. 
In the clear Black Sea waters CDOM content varied from 0.6 to $2.2 \mathrm{mg} / \mathrm{l}$; most frequently, (with $27 \%$ repeatability) the values within $1.8-2.0 \mathrm{mg} / \mathrm{l}$ range were observed (Fig. 5, b). Therefore, as a criterion by which the surface waters of the Black Sea origin with no anthropogenic CDOM admixture can be defined, the concentration of this matter (which does not exceed $1.9 \mathrm{mg} / \mathrm{l}$ ) can be taken. It should be pointed out that this criterion, calculated on the basis of hydro-optical observations, almost coincides with the one obtained in [2] on the basis of chemical analysis (according to it, typical CDOM content in upper layer of clear open Black Sea waters makes up $2 \mathrm{mg} / \mathrm{l}$ ).

Various background of CDOM content in the waters ineracting in the Kerch Strait may be due to the vertical distribution features of this element.

In the clear Sea of Azov waters, in Northern shallow (2-6 m) part of the strait CDOM field vertical stratification, as well as the one of thermohaline field, is absent (Fig. 6, $a$ ).
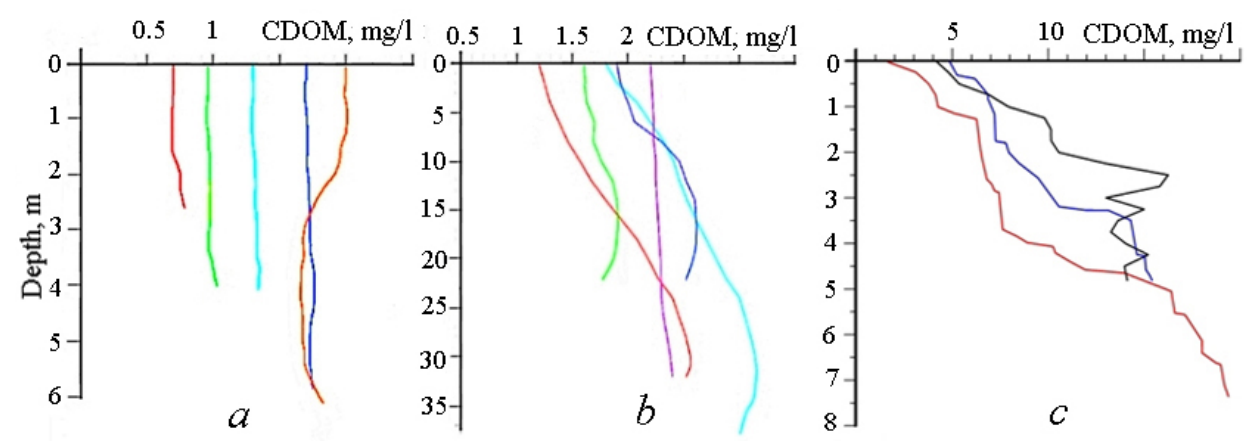

Fig. 6. Examples of CDOM profiles (z) in the Kerch Strait: unpolluted waters of the Sea of Azov (a), the Black Sea $(b)$; the waters of polluted areas $(c)$

In clear stratified Black Sea waters, in the Southern deep (15 - $30 \mathrm{~m})$ part of the strait CDOM profile $(z)$ is characterized by the presence of upper quasihomogeneous layer with subsurface maximum which is located deeper. Its nature can be related to CDOM accumulation in the layer of density leap (Fig. 6, $b$ ). Therefore, in the Black Sea pre-strait zone upper layer of waters can be fed up with CDOM from subsurface horizons when vertical exchange intensification takes place.

This assumption is confirmed by experiment data. Thus, according to the results of the Kerch Strait surveys carried out in August [10] and September 2011, it is revealed that under conditions of persistent wind of Western quarter a pronounced upwelling with the focuses situated in Kerch and Kamysh-Burun Bay is observed near the strait shore. In this place, the minimum temperature, which was by $2-3{ }^{\circ} \mathrm{C}$ lower than the one of surrounding background, and salinity increased by $1-2$ psu were recorded. The Black Sea subsurface waters saturated with CDOM $(2.3-3.1 \mathrm{mg} / \mathrm{l})$ got to the surface in the system of compensatory currents.

Thus, subsurface structural zone of the Black Sea may be considered as a natural CDOM source in the Kerch Strait. 
Main anthropogenic CDOM sources in the Southern part of the Kerch Strait were defined. They are the harbors, industrial plants situated at the shore, sewage collectors, cargo terminals, off-shore transshipment sites and ground landfills [8]. Lenses of polluted waters, produced by these sources, are characterized by high content of CDOM (4-18 mg/l), petroleum products and total suspended matter [12]. They significantly distort the structure of CDOM natural field in the strait and, correspondingly, its front section.

Depending on degree of strait water pollution, which has almost no effect in the thermohaline field, the front section in the CDOM field is not always enough marked. It changes the forms, shifts against thermohaline front and sometimes it changes the sign of horizontal gradient.

Characteristic features of CDOM concentration vertical structure in polluted waters of the water area under investigation are its high content and well-marking nonmonotonic profile with fine-structured intrusive signs (Fig. 6, c). According to [13], similar features are characteristic of waters polluted with CDOM of other areas of the Crimean coast.

Conclusion. On the basis of the analysis of data obtained during the series of expeditions carried out by MHI, CDOM characteristic concentration was assessed, the sources were revealed and the main signs of CDOM field structure in the waters of the Sea of Azov and Kerch Strait were defined.

In general, CDOM concentration $(1-3 \mathrm{mg} / \mathrm{l})$ determined on the basis of optical methods and which is characteristic of the prevailing part of the Sea of Azov area turned out to be significantly lower than available estimates $(\sim 10 \mathrm{mg} / \mathrm{l})$. For the Black Sea waters, the data of our measurements coincided with previously obtained values of content of this matter ( $\sim 2 \mathrm{mg} / \mathrm{l})$ which were carried out on the basis of chemical methods.

A close correlative feedback between the salinity and CDOM content, which confirms the known statement that river runoff is one of the main DOM sources in the sea, was found. However, it is shown that it is significant for the small water areas of Eastern and Northern coasts as a factor forming the DOM field.

In the Sea of Azov CDOM field is inhomogeneous. Predominant part of its water area is characterized by small concentration of this matter $(1-3 \mathrm{mg} / \mathrm{l})$. In the waters of Northern and Eastern coasts affected by river runoff, CDOM content is by an order higher. In unpolluted sea waters CDOM field is vertically homogeneous.

It is revealed that transformed river waters with high CDOM content do not penetrate into the Southern regions of the sea and the Kerch Strait.

In the Kerch Strait, in CDOM field a front section which coincides with the main thermohaline front delimiting the waters of the Sea of Azov and the Black Sea interacting in the strait. The Sea of Azov and the Black Sea waters penetrating into the strait have (in addition to the known thermohaline signs) their own CDOM concentration. Moreover, in the waters of the Sea of Azov it turned out to be lower $(1.6 \mathrm{mg} / \mathrm{l})$ in comparison with the Black Sea ones $(1.9 \mathrm{mg} / \mathrm{l})$.

Subsurface Black Sea waters saturated with CDOM are the natural source of this matter in the Kerch Strait. 
The signs of vertical structure of CDOM content field in the Kerch Strait were revealed. In clear waters of the Sea of Azov it is weakly stratified. In the clear Black Sea waters in the layer of density leap the maximum of concentration of this matter was recorded. A well-marked non-monotonic $\operatorname{CDOM}(z)$ profile with finestructured intrusive signs is typical for the polluted areas.

Lenses of polluted waters, produced by these sources, are characterized by high content of CDOM $(4-18 \mathrm{mg} / \mathrm{l})$, petroleum products and total suspended matter [12]. They significantly distort the structure of CDOM natural field in the strait and, correspondingly, its front section.

CDOM natural field of considered water areas is often distorted by lenses with high CDOM concentration ( $4-18 \mathrm{mg} / \mathrm{l})$ which are caused by an anthropogenic effect. Principle anthropogenic sources of CDOM are related to the functioning of harbors, industrial plants situated at the shore, sewage collectors, cargo terminals, off-shore transshipment sites and ground landfills.

\section{REFERENCES}

1. Gorshkova, O.M., Patsaeva, S.V. \& Fedoseeva, E.V. [et al.], 2009, "Fluorestsentsiya rastvorennogo organicheskogo veshchestva prirodnoy vody [Fluorescence natural water dissolved organic matter]”, Voda: khimiya i ekologiya, no. 11, pp. 31-37 (in Russian).

2. Khaylov, K.M., 1975, "Ekologicheskiy metabolizm v more [Ecological metabolism in the sea]”, Kiev, Naukova dumka, 250 p. (in Russian).

3. Skopintsev, B.A., 1975, "Formirovanie sovremennogo khimicheskogo sostava vod Chernogo morya [Formation of modern chemical composition of the Black Sea waters]”, Leningrad, Gidrometeoizdat, 338 p. (in Russian).

4. Saraceno, J.F., Pellerin, B.A. \& Downing, B.D. [et al.], 2009, "High-frequency in situ optical measurements during a storm event: Assessing relationships between dissolved organic matter, sediment concentrations, and hydrologic processes”, J. Geophys. Res., vol. 114, G00F09, doi:10.1029/2009JG000989.

5. http://www.ecodevice.narod.ru/turbidimeter/turbidimeter.htm (Access date 16.06.2016).

6. Lomakin, P.D., Chepyzhenko, A.I. \& Chepyzhenko, A.A., 2010, "Razmyv Berdyanskoy kosy (Azovskoe more) posle shtormovogo nagona v noyabre 2007 goda [Berdyanskaya Spit (the Azov Sea) erosion after the storm surge in November 2007]”, Geologiya i poleznye iskopaemye Mirovogo okeana, no. 2, pp. 63-68 (in Russian).

7. http://chem21.info/info/69623/ (Access date 10.04.2016).

8. http://национальныйатлас.pф/cd2/index.html (Access date 21.04.2016).

9. Boss, E., Pegau, W.S. \& Zaneveld ,J.R.V. [et al.], 2001, "Spatial and temporal variability of absorption by dissolved material at a continental shelf”, J. Geophys. Res., vol. 106, no. C5, pp. 9499-9507.

10. Lomakin, P.D., Trotsenko, B.G. \& Chepyzhenko, A.I. [et al.], 2011, “Gidrofizicheskie usloviya i otsenka biologicheskogo zagryazneniya vod v Kerchenskom prolive v avguste 2011 goda [Hydrophysical conditions and estimation of water biological pollution in the Kerch Strait in August 2011]", Ekologicheskaya bezopasnost' pribrezhnoy i shel'fovoy zon $i$ kompleksnoe ispol'zovanie resursov shel'fa, iss. 25 part 1, pp. 267-273 (in Russian).

11. Lomakin, P.D., Trotsenko, B.G. \& Chepyzhenko, A.I. [et al.], 2014, “Hydrophysical conditions, the total suspended matter field and biological pollution estimation of the Kerch Strait waters in September 2011 following Ukrainian-Russian expedition”, Tr. YugNIRO, vol. 52, pp. 11-20. 
12. Lomakin, P.D., Spiridonova, E.O., 2010, "Prirodnye i antropogennye izmeneniya $v$ polyakh vazhneyshikh abioticheskikh elementov ekologicheskogo kompleksa Kerchenskogo proliva v techenie dvukh poslednikh desyatiletiy [Natural and anthropogenic changes in the fields of most important abiotic elements of the Kerch Strait ecologic complex in the past two decades]”, Sevastopol, ECOSI-Gidrofizika, 118 p. (in Russian).

13. Lomakin, P.D., Chepyzhenko, A.I. \& Chepyzhenko, A.A., 2007, “Otsenka kontsentratsii poley summarnoy vzvesi i rastvorennogo organicheskogo veshchestva $v$ bukhtakh krymskogo poberezh'ya na osnove dannykh opticheskikh izmereniy [Estimation of total organic matter concentration fields in the Crimean coast bays on the basis of optival measurement data]", Ekologicheskaya bezopasnost' pribrezhnoy i shel'fovoy zon i kompleksnoe ispol'zovanie resursov shel'fa, iss. 15, pp. 168-176 (in Russian). 